\title{
CHALLENGE AND RESPONSE
}

The social nature of the discipline of archaeology

Stephen Shennan

I'm not sure I agree with the definition of the problem as set out by the authors but I certainly agree with the solution they propose: real interdisciplinary collaboration is the only way and it isn't necessarily easy because of the different languages that different specialists speak and the assumptions they bring to their work. In my experience most archaeologists these days are keen to make use of the results of archaeological science and do not have a set of filters that they automatically apply, but it would be interesting to do an analysis of this. Most of the archaeologists I know are prehistorians and the result might be different for medievalists or Classical archaeologists who have extensive written records; indeed, the medieval historian Peter Sawyer used to say that archaeology is an expensive way of finding out what we already know. Palaeolithic archaeologists, on the other hand, feel they need every scrap of evidence they can get using whatever methods may be available. There's also a question of training. In some education systems, such as England's, academics specializing in the Classical or medieval periods may have given up studying any scientific subject at the age of I6; Palaeolithic archaeologists are much more likely to have come up through a scientific route. This is especially an issue with quantitative literacy, a point to which I will return.

As the authors point out, the use of scientific methods goes back to the beginnings of the discipline, especially in Scandinavia, and having scientific specialists of various kinds on fieldwork teams has been stand- 
ard practice for decades, though for much of that time they have been mere providers of appendices to excavation reports and it is only more recently that they have begun to be incorporated fully into the archaeological research process.

However, many archaeologists are natural sceptics, whatever the novelty that's being proposed, scientific or anything else, and this is a perfectly reasonable position to take, examining them to see if they're all that is being claimed by their advocates. In fact, this is the basis of the Popperian approach that the authors espouse. It's worth remembering that in the early years there was actually a lot of opposition in some quarters both to radiocarbon dating and to its calibration, and some archaeologists accepted the dates that fitted their preconceptions and rejected others as "archaeologically unacceptable". If you were an expert practitioner of a strong existing chronological system, like the Montelian system of typology and cross-dating for later prehistoric Europe, there was no reason why you should throw it over at the first sign of problems. Again, it's the debate between opponents and proponents of different views, in this as in other aspects of archaeology, that makes the discipline progress. In short, it's not so clear that the situation with archaeological science is so different today from what it was in the past; in fact, I'm sure that students of archaeology today are more scientifically knowledgeable than they were in the past because virtually all archaeology degrees include an element of archaeological science.

What about going the other way, scientists who produce interesting results in their own disciplines but fail to engage with archaeologists regarding their significance and interpretation? The authors provide a good example here with their example of the dog genome study, and I tend to agree with the implication that a certain amount of arrogance exists on the part of some scientists, who don't feel they need to engage with archaeology and archaeologists. It's also true that many such studies appear in the highest-profile journals and attract a lot of press attention. But it's also archaeologists' fault that what they produce doesn't attract attention to the same extent. As Lidén and Eriksson point out later in the paper, it is indeed disappointing that it's Jared Diamond writing the great syntheses like Guns, Germs and Steel, but that's our fault, not his.

Their second example, concerning the use of the term "nuclear family", isn't quite the same, not least because this paper does have an archaeologist as one of the authors. I think they judge it rather harshly but it's good to be reminded of the loaded nature of many kinship terms and the need to be careful in their use. Exhibit C, lack of source of criticism, about the acceptance or otherwise of dates from cremated bone, is another example of the case I've already noted above, of archaeolo- 
gists designating dates they don't like as "archaeologically unacceptable" and looking for reasons to reject them.

The observations about stable isotope analysis are well taken. Part of the reason for the shift they suggest in archaeological attitudes to them must surely be part of the now well-established sequence of the development and application of scientific methods in archaeology that I've mentioned above: initial euphoria at the new potential and overinterpretation of results -> disillusionment as the sceptics weigh in with their critiques -> a more balanced assessment in which shortcomings are gradually addressed and interpretations are qualified. There may well be more going on in the stable isotopes case, though, as the authors suggest. In Britain much of the debate about these techniques focussed on the use of stable isotope analysis to identify changes in diet at the transition to farming and the vigorous challenge to the results that came out arose from the discovery that there was a rapid major shift from strongly aquatic/maritime diets to heavily terrestrial ones, contradicting the prevailing orthodoxy that the transition involved a gradual change from foraging to farming on the part of indigenous populations. Once again, though, in some respects the debate is just the normal reluctance of adherents to a hypothesis to give it up at the first sign of a challenge.

In fact, at least in Britain the stable isotopes case falls under the same heading as Lidén and Eriksson's fifth example, unwelcome results. They illustrate this with reference to the conclusions of a whole genome aDNA analysis of Swedish skeletons from the TRB and Pitted Ware cultures and their comparison with modern gene distributions, that farming was introduced by immigrants from southern Europe rather than being locally adopted. For the reasons that the authors note, the results cannot be considered conclusive but they are certainly right to suggest that the controversy provoked also stems from the fact that, as in Britain, the extent to which farming was introduced by migrants or adopted by indigenous foragers is not just a matter of weighing evidence about different hypotheses; it is also about paradigmatic commitments and the link between paradigmatic commitment and values. The interpretation and use of genetic information has a lot of unsavoury associations with a long history: as a result invocations of genetic evidence have been construed by some as racist. Similarly, to suggest that foragers didn't introduce farming was taken to imply colonialist attitudes, a belief that foragers lacked agency and were somehow inferior; indigenists as "goodies" and migrationists as "baddies". In some respects, then, the debate over the Skoglund et al. study reflects the legacy of the anti-scientific attitudes of early post-processualism and the argument of authors such as Shanks and Tilley that present-day ideological interests were much 
more important influences on archaeological interpretation than evidence: to be scientific was to be fascistic, or almost. Fortunately, such views are now far less influential than they were in the I990s, and the change is well reflected in the move by the leader of the first generation of post-processualists, Ian Hodder, to direct at Çatal Höyük perhaps the most scientific-method-intensive excavation ever conducted, in pursuit of aims that are still in many respects post-processual.

There is no doubt that understanding genetic evidence, ancient and modern, is the current frontier in interdisciplinary archaeological science studies and it exemplifies the importance of the authors' goal of collaborative research based on good communication. It has the potential to provide answers to big questions that seemed forever out of reach, but geneticists differ in their interpretations just as much as archaeologists do, and making sense of the data requires the use of complex mathematical modelling techniques that can lead to counter-intuitive conclusions; for example, the fact that the highest prevalence of lactase persistence is in northern Europe does not mean it originated there: genetic and demographic simulation shows that it most probably originated in the south-east. In this respect the quantitative deficit characteristic of archaeologists can make communicating difficult. I agree completely with the Popper quotation Lidén and Eriksson endorse, that we're students of problems not subjects, but we're all trained in subjects and that is not just a historical leftover. We need the time to learn the method and theory for dealing with particular kinds of evidence and have to take the consequences. Unfortunately for archaeology, Colin Renfrew's prophecy many years ago now that the days of the innumerate are numbered has not yet come true.

Stephen Shennan UCL Institute of Archaeology 3 I-34 Gordon Square London $\mathrm{WCIH}$ oPY United Kingdom 